\title{
ANTITUMOR ACTIVITY OF TRIENOMYCIN A ON MURINE TUMORS
}

\author{
Kanki Komiyama, Yumiko Hirokawa, Hiroko Yamaguchi, \\ Shinji Funayama, Kazuaki Masuda, Yumi Anraku, \\ IWAO UMEZAWA and SATOSHI ŌMURA \\ The Kitasato Institute, \\ 5-9-1 Shirokane, Minato-ku, Tokyo 108, Japan \\ (Received for publication May 11, 1987)
}

\begin{abstract}
The antitumor activity of a novel ansamycin antibiotic, trienomycin A, against various murine tumors was studied with two treatment schedules. The intraperitoneal injection of the antibiotic showed remarkable antitumor activity on sarcoma 180 and P388 leukemia at doses of 160 or $320 \mathrm{mg} / \mathrm{kg}$, showing $151 \%$ and $100 \%$ increase in life span, respectively.

Trienomycin A inhibited the growth of Ehrlich and Meth A cells in vitro at doses of $0.1 \sim$ $0.4 \mu \mathrm{g} / \mathrm{ml}$ when the cells were exposed to the antibiotic for 72 hours. The incorporation of $\left[{ }^{3} \mathrm{H}\right]$ thymidine into acid precipitable material in HeLa cells was slightly more marked than that of $\left[{ }^{3} \mathrm{H}\right]$ uridine and $\left[{ }^{3} \mathrm{H}\right]$ leucine when the cells were exposed to 0.04 or $0.08 \mu \mathrm{g} / \mathrm{ml}$ of trienomycin $\mathrm{A}$ for 4 hours. It appeared that trienomycin $\mathrm{A}$ showed antitumor activity by direct cytotoxic action.
\end{abstract}

Trienomycin A, a novel ansamycin antibiotic, was first reported by UMEZAWA et al. as a cytocidal antibiotic ${ }^{1)}$. Trienomycin $\mathrm{A}$ is unique among the benzenoid ansamycin antibiotics in that it does not have a $p$-quinone or $p$-hydroquinone moiety in the structure ${ }^{2)}$. The benzenoid moiety of trienomycin A is somewhat similar to that of maytansinoids derived from plant materials ${ }^{3)}$.

Thereafter, two other fractions, trienomycins $B$ and $C$, were isolated from the same fermentation broth $^{4}$. Among the trienomycins, substance A showed remarkable cytocidal activity against HeLa cells in vitro. The experiments reported herein were designed mainly to elucidate the antitumor activity of trienomycin $\mathrm{A}$ on transplantable murine tumors.

\section{Materials and Methods}

Animals

Female ICR, $d d \mathrm{Y}, \mathrm{CDF}_{1}$ and $\mathrm{C} 57 \mathrm{BL} / 6$ mice, 6 weeks of age, were purchased from the Shizuoka Laboratory Animal Center (Hamamatsu, Japan).

Agents

Trienomycin A was isolated and purified according to the some procedure reported previously ${ }^{1}$. Trienomycin A was dissolved in a small amount of $\mathrm{MeOH}$ and Tween 80 , diluted with saline and injected intraperitoneally into tumor bearing mice. $\left[{ }^{3} \mathrm{H}\right] \mathrm{Thymidine}\left(\left[{ }^{3} \mathrm{H}\right] \mathrm{TdR}, 22 \mathrm{Ci} / \mathrm{mmol}\right),\left[{ }^{3} \mathrm{H}\right]$ uridine $\left(\left[{ }^{3} \mathrm{H}\right] \mathrm{UR}, 6.5 \mathrm{Ci} / \mathrm{mmol}\right)$ and $\left[{ }^{3} \mathrm{H}\right] \mathrm{leucine}(60 \mathrm{Ci} / \mathrm{mmol})$ were obtained from the Radiochemical Centre, Amersham, UK.

\section{Tumor Cell Lines and Antitumor Activity}

Tumor cells were maintained by weekly passage intraperitoneally in mice. Tumor cell lines and mice used are listed in Table 1. Antitumor activity was evaluated by the increase in life span (ILS): (T/C-1) $\times 100(\%)$, where " $T$ " is the mean survival days (MSD) of the treated group and " $\mathrm{C}$ " is the MSD of the control group. Survival of the mice was scored 60 days after inoculation of tumors, 
Table 1. Tumors used in this experiment.

\begin{tabular}{llcc}
\hline \multicolumn{1}{c}{ Tumor } & Mice & \multicolumn{2}{c}{ Inoculum } \\
\cline { 3 - 3 } & & Size (cells/mouse) & Site \\
\hline Ehrlich carcinoma & $d d \mathrm{Y}$ & $2.5 \times 10^{6}$ & ip \\
Sarcoma 180 & $\mathrm{ICR}$ & $1 \times 10^{6}$ & ip \\
IMC carcinoma & $\mathrm{CDF}_{1}$ & $1 \times 10^{6}$ & ip \\
P388 leukemia & $\mathrm{CDF} F_{1}$ & $1 \times 10^{5}$ & ip \\
B16 melanoma & $\mathrm{C} 57 \mathrm{BL} / 6$ & $3 \times 10^{5}$ & ip \\
Lewis lung carcinoma & $\mathrm{C} 57 \mathrm{BL} / 6$ & $3 \times 10^{5}$ & ip \\
\hline
\end{tabular}

Table 2. Cytocidal activity of trienomycin $\mathrm{A}$ against Ehrlich and Meth $\mathrm{A}$ cells in vitro.

\begin{tabular}{cccccc}
\hline \multirow{2}{*}{$\begin{array}{c}\text { Concentration } \\
(\mu \mathrm{g} / \mathrm{ml})\end{array}$} & \multicolumn{2}{c}{ Ehrlich cells } & & \multicolumn{2}{c}{ Meth A cells } \\
\cline { 2 - 3 } \cline { 5 - 6 } & $\begin{array}{c}\text { Cell No./plate } \\
\left(\times 10^{4}\right)\end{array}$ & $\begin{array}{c}\text { Inhibition } \\
(\%)\end{array}$ & & $\begin{array}{c}\text { Cell No./plate } \\
\left(\times 10^{4}\right)\end{array}$ & $\begin{array}{c}\text { Inhibition } \\
(\%)\end{array}$ \\
\hline Control & $88.1 \pm 15.9$ & 0 & & $43.0 \pm 1.9$ & 0 \\
1.6 & $6.5 \pm 2.2^{*}$ & 92.7 & & $8.6 \pm 2.1^{* *}$ & 80.0 \\
0.4 & $19.7 \pm 4.1^{*}$ & 77.6 & & $14.9 \pm 1.8^{* *}$ & 65.3 \\
0.1 & $66.4 \pm 4.5$ & 24.5 & & $33.6 \pm 5.8^{*}$ & 23.3 \\
0.025 & $83.7 \pm 7.8$ & 5.0 & & $39.0 \pm 4.0$ & 9.3 \\
0.006 & $79.3 \pm 7.4$ & 9.9 & & $45.8 \pm 5.0$ & 0 \\
\hline
\end{tabular}

* $P<0.05$. ** $P<0.01$.

and mice remaining alive after this period of observation were considered cured.

Cytotoxicity for Tumor Cells

Ehrlich and Meth A tumor cells were maintained in RPMI 1640 medium supplemented with $10 \%$ fetal bovine serum and kanamycin $(50 \mu \mathrm{g} / \mathrm{ml})$ at $37^{\circ} \mathrm{C}$. To determine the cytotoxicity of trienomycin A, Ehrlich cells $\left(7.5 \times 10^{4}\right)$ or Meth A cells $\left(3.8 \times 10^{4}\right)$ in $1.5 \mathrm{ml}$ of medium were placed in a tissue culture plate (Falcon, 24 wells) and incubated for 48 hours at $37^{\circ} \mathrm{C}$ in a $5-\% \mathrm{CO}_{2}-95 \%$ air atmosphere. To each culture well was added $0.5 \mathrm{ml}$ of fresh medium containing a different concentration of trienomycin A, and they were reincubated. After further 72 hours of incubation the cells were counted by a hemocytometer.

Measurement of Macromolecular Synthesis

HeLa cells $\left(5 \times 10^{4} / 0.2 \mathrm{ml}\right)$ were plated on a cover slip (LUX, $13 \mathrm{~mm}$ i.d.) inserted previously into a tissue culture plate (Falcon, 24 wells), and $2 \mathrm{ml}$ of minimum essential medium was added after 3 hours. Following 48 hours of incubation, each culture well was refilled with fresh medium containing a different concentration of the antibiotic. The cells were exposed to trienomycin A for 1 and 4 hours. One hour before termination of the culture, various precursors were added. At the end of the incubation period, cells were washed once with ice-cold phosphate buffered saline, and three times with icecold $5 \%$ TCA. The radioactivity of acid-precipitable material on the cover slip was measured by an Aloka liquid scintillation spectrometer.

\section{Results}

\section{Cytotoxicity for Tumor Cells}

Cytotoxic activity of trienomycin A was determined on Ehrlich carcinoma cells and Meth A fibrosarcoma cells in vitro. When the cells were exposed to trienomycin A for 72 hours, cell growth was remarkably suppressed at a dose of $0.4 \mu \mathrm{g} / \mathrm{ml}$ (Table 2). 
Table 3. Antitumor activity of trienomycin A.

\begin{tabular}{|c|c|c|c|c|c|c|}
\hline \multirow{2}{*}{$\begin{array}{c}\text { Dose } \\
(\mathrm{mg} / \mathrm{kg})\end{array}$} & \multicolumn{2}{|c|}{ Sarcoma 180} & \multicolumn{2}{|c|}{ P388 leukemia } & \multicolumn{2}{|c|}{ IMC carcinoma } \\
\hline & MSD & ILS $(\%)$ & MSD & $\operatorname{ILS}(\%)$ & MSD & ILS $(\%)$ \\
\hline Saline & $10.0 \pm 0.8$ & 0 & $10.4 \pm 0.5$ & 0 & $16.6 \pm 2.6$ & 0 \\
\hline $32 \times 10$ & $22.8 \pm 3.9 *$ & 128 & $18.2 \pm 2.3^{*}$ & 75 & $27.4 \pm 4.3^{*}$ & 65 \\
\hline $16 \times 10$ & $24.8 \pm 3.4^{*}$ & 148 & $17.0 \pm 2.2^{*}$ & 64 & $21.6 \pm 2.7^{*}$ & 30 \\
\hline $8 \times 10$ & $22.4 \pm 5.9^{*}$ & 124 & $15.2 \pm 1.1^{*}$ & 46 & $20.2 \pm 1.6^{*}$ & 22 \\
\hline $4 \times 10$ & $13.0 \pm 1.8^{*}$ & 30 & $13.6 \pm 0.5^{*}$ & 31 & $18.4 \pm 2.6$ & 11 \\
\hline $0.5 \times 10(\mathrm{MMC})$ & $38.6 \pm 5.9^{*}$ & 286 & $23.0 \pm 4.0^{*}$ & 121 & $53.0 \pm 6.0^{*}$ & 219 \\
\hline Saline & $11.8 \pm 0.8$ & 0 & $10.2 \pm 0.4$ & 0 & $14.5 \pm 1.0$ & 0 \\
\hline $64 \times 5$ & $5.8 \pm 0.8$ & -48 & $20.4 \pm 3.3^{*}$ & 100 & $5.4 \pm 0.9$ & -63 \\
\hline $32 \times 5$ & $29.6 \pm 11.3^{*}$ & 151 & $17.8 \pm 0.4^{*}$ & 75 & $22.6 \pm 2.7^{*}$ & 56 \\
\hline $16 \times 5$ & $25.6 \pm 7.8^{*}$ & 117 & $14.0 \pm 0.9^{*}$ & 37 & $19.2 \pm 1.3^{*}$ & 32 \\
\hline $8 \times 5$ & $23.2 \pm 9.4^{*}$ & 97 & $13.7 \pm 0.8^{*}$ & 34 & ND & \\
\hline \multirow{2}{*}{$\begin{array}{c}\text { Dose } \\
(\mathrm{mg} / \mathrm{kg})\end{array}$} & \multicolumn{2}{|c|}{ B16 melanoma } & \multicolumn{2}{|c|}{ Lewis lung carcinoma } & \multicolumn{2}{|c|}{ Ehrlich carcinoma } \\
\hline & MSD & $\operatorname{LLS}(\%)$ & MSD & ILS $(\%)$ & MSD & ILS $(\%)$ \\
\hline Saline & $19.4 \pm 1.9$ & 0 & $16.6 \pm 0.5$ & 0 & $18.5 \pm 1.3$ & 0 \\
\hline $32 \times 10$ & ND & & ND & & $37.0 \pm 2.6^{*}$ & 100.0 \\
\hline $16 \times 10$ & $22.2 \pm 0.4^{*}$ & 14.4 & $20.6 \pm 0.9^{*}$ & 24.0 & $25.6 \pm 7.2$ & 38.4 \\
\hline $8 \times 10$ & $21.0 \pm 2.3$ & 8.2 & $19.2 \pm 2.2$ & 15.7 & $18.3 \pm 1.5$ & 0 \\
\hline $4 \times 10$ & $22.0 \pm 1.4$ & 13.4 & $16.4 \pm 3.1$ & 0 & $18.8 \pm 1.5$ & 1.6 \\
\hline $0.5 \times 10(\mathrm{MMC})$ & $23.0 \pm 2.0^{*}$ & 18.6 & $19.4 \pm 2.5$ & 16.9 & $44.0 \pm 5.0^{*}$ & 138.0 \\
\hline Saline & $21.0 \pm 1.2$ & 0 & $22.5 \pm 0.5$ & 0 & $19.4 \pm 1.3$ & 0 \\
\hline $32 \times 5$ & $26.8 \pm 3.5^{*}$ & 27.6 & $24.8 \pm 3.1$ & 10.2 & $20.4 \pm 2.2$ & 5.0 \\
\hline $16 \times 5$ & $28.2 \pm 3.0^{*}$ & 34.3 & $20.2 \pm 2.2$ & 0 & $20.8 \pm 1.5$ & 7.0 \\
\hline $8 \times 5$ & $29.2 \pm 3.8^{*}$ & 39.0 & $22.0 \pm 6.2$ & 0 & $17.4 \pm 1.2$ & 0 \\
\hline
\end{tabular}

* $P<0.05$.

MMC: Mitomycin C.

ND: Not done.

Fig. 1. Effect of trienomycin A on the synthesis of macromolecules in HeLa cells. Thymidine, uridine, $\square$ leucine incorporation.

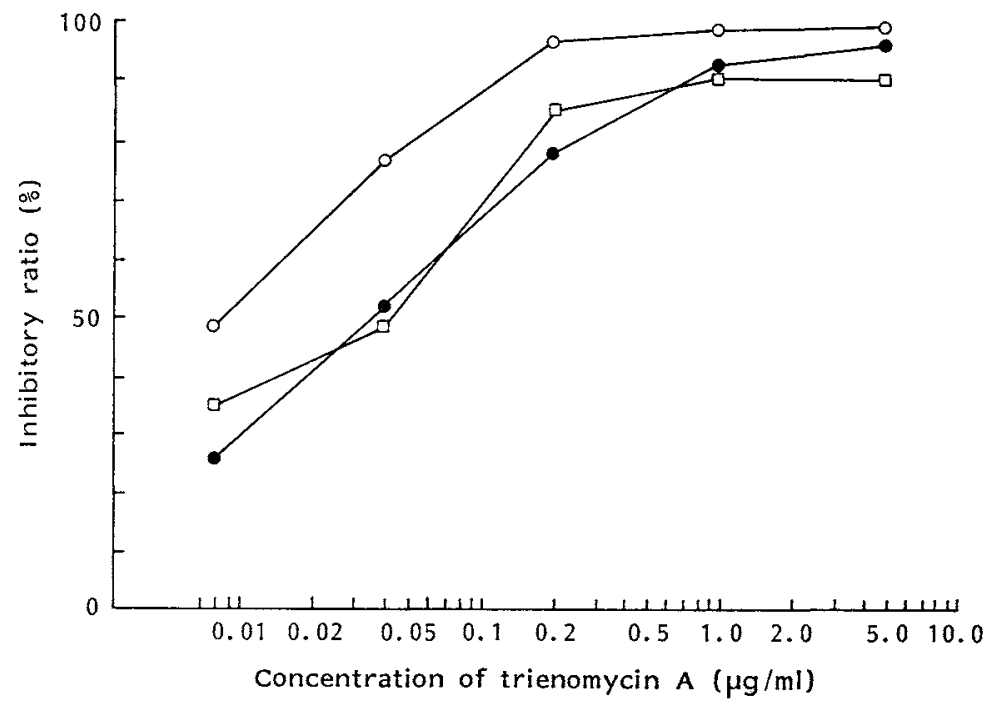




\section{Antitumor Activity}

Trienomycin A was evaluated for antitumor activity against murine tumors. According to the ILS of tumor bearing mice, trienomycin A was effective against sarcoma 180 , IMC carcinoma, P388 leukemia and Ehrlich carcinoma at doses of $40 \sim 320 \mathrm{mg} / \mathrm{kg}$. No definite difference was observed in the effect of trienomycin A between 5- and 10-day treatments on sarcoma 180, P388 leukemia and IMC carcinoma. Only a slight
Table 4. Antibacterial activity of trienomycin A.

\begin{tabular}{lc}
\hline \multicolumn{1}{c}{ Test organism } & $\begin{array}{c}\text { MIC } \\
(\mu \mathrm{g} / \mathrm{ml})\end{array}$ \\
\hline Piricularia oryzae KF 180 & 100 \\
Mucor racemosus KF 223 (IFO 4581) & $>100$ \\
Saccharomyces sake KF 26 & $>100$ \\
Candida albicans KF 1 & $>100$ \\
Penicillium herquei KF 227 (IFO 4674) & 100 \\
Aspergillus niger KF 103 (ATCC 6275) & $>100$ \\
\hline
\end{tabular}

MIC was determined by the conventional serial dilution method using potato - glucose agar.

life prolongation effect was observed on Lewis lung carcinoma and B16 melanoma by the 10-day or the 5-day treatment schedules, respectively (Table 3 ).

\section{Effect of Trienomycin A on Macromolecular Synthesis}

The effect of trienomycin $A$ on the incorporation of $\left[{ }^{3} \mathrm{H}\right] \mathrm{TdR},\left[{ }^{3} \mathrm{H}\right] \mathrm{UR}$ and $\left[{ }^{3} \mathrm{H}\right]$ leucine into acidprecipitable macromolecules of HeLa cells was determined.

When HeLa cells were exposed to $0.008 \sim 0.2 \mu \mathrm{g} / \mathrm{ml}$ of the antibiotic for 4 hours, the incorporation of $\left[{ }^{3} \mathrm{H}\right] \mathrm{TdR}$ into acid precipitable material was slightly more marked than that of the other two precursors at lower concentrations of the antibiotic (Fig. 1).

\section{Discussion}

As shown in this study, trienomycin A possessed antitumor activity against murine tumors. The antibiotic also inhibited the growth of mammalian cells at doses of $0.4 \sim 0.1 \mu \mathrm{g} / \mathrm{ml}$, whereas the growth inhibition of bacteria was weak as shown in the previous paper (paper-disk method) ${ }^{1)}$ and in Table 4 (agar dilution method). Among several ansamycin antibiotics, mycotrienins I and II are similar to trienomycin $\mathrm{A}$ in structure ${ }^{\mathrm{s})}$. However, mycotrienins did not show definite anti-P388 activity in vivo in contrast to antifungal activity in vitro ${ }^{6}$. The structure of trienomycin $\mathrm{A}$ is unique among benzenoid ansamycin antibiotics in that the antibiotic does not have a $p$-quinone or $p$-hydroquinone moiety in its structure. This unique structure could be important because it possesses antitumor activity instead of antifungal activity. Cytotoxicity was decreased when the triene moiety of trienomycin A was reduced by catalytic hydrogenation (data not shown). This fact indicated that the triene moiety is essential for the activity of trienomycin A.

Inhibition of incorporation of $\left[{ }^{3} \mathrm{H}\right] \mathrm{TdR}$ into acid precipitable materials of mammalian cells was relatively more marked than that of the other two precursors. However, no definite characteristic was observed in the present brief experiment. We are now investigating the mechanism of action of this antibiotic, and the results will be reported elsewhere.

\section{Acknowledgment}

This work was supported by a Grant-in-Aid from the Ministry of Health and Welfare and the Ministry of Education, Science and Culture, and by funds from the Japan Keirin Association.

\section{References}

1) Umezawa, I.; S. Funayama, K. Okada, K. Ifasaki, J. Satoh, K. Masuda \& K. Komiyama: Studies on a novel cytocidal antibiotic, trienomycin A. Taxonomy, fermentation, isolation, and physico-chemical and biological characteristics. J. Antibiotics 38: 699 705, 1985

2) Funayama, S.; K. OKada, K. Komiyama \& I. Umbzawa: Structure of trienomycin A, a novel cytocidal ansamycin antibiotic. J. Antibiotics 38: 1107 1109, 1985 
3) ReIder, P. J. \& D. M. Roland: Maytansinoids. In The Alkaloids. Vol. XXIII. Ed., A. Brossi, pp. $71 \sim 156$, Academic Press, Inc., Orland, 1984

4) Funayama, S.; K. Okada, K. Iwasaki, K. Komiyama \& I. Umezawa: Structures of trienomycins A, B and $C$, novel cytocidal ansamycin antibiotics. J. Antibiotics 38: $1677 \sim 1683,1985$

5) Sugrta, M.; T. Sasaki, K. Furihata, H. Seto \& N. ŌTake: Studies on mycotrienin antibiotics, a novel class of ansamycins. II. Structure elucidation and biosynthesis of mycotrienins I and II. J. Antibiotics 35: $1467 \sim 1473,1982$

6) Sugita, M.; Y. Natori, T. Sasaki, K. Furihata, A. Shimazu, H. Seto \& N. Ōtake: Studies on mycotrienin antibiotics, a novel class of ansamycins. I. Taxonomy, fermentation, isolation and properties of mycotrienins I and II. J. Antibiotics 35: 1460 1466, 1982 